Printed Version: (ISSN 2090-5262)

Online Version: (ISSN 2090-5270)

March 2013, Volume 3, No. 1 Pages (151 - 163)

\title{
The Effect of Using Agility Drills on Developing Some Speed Abilities of Junior Soccer Players
}

\author{
Mahmoud Hassan Elhofy*
}

*Assistant professor,department ofsports, Faculty of physical Education, Menoufia University

\begin{abstract}
This research aims to design a program for agility drills as an attempt to see its impact on agility and some speed abilities of junior soccer player. The researcher used the experimental method by design "pre-measurement - post-measurement" to one experimental set. And research sample was selected by intended way from juniors under 17 years of National Bank Club in Cairo and they were 23 players (8 defenders, 7 Midfielders, 8 attackers), and the place of applying the research experiment and pre and post-measurements was specified at the fields of National Bank Club in Giza district of soccer. The temporal scale of the program in the period from 07.24 to 09.29 / 2010 during (10) weeks of the preparation period, starting with the third week of 2010/2011 season. And the most important results were that the training program has a positive impact in the development speed and agility abilities under study in the play's (defense, midfield, offensive) lines, and the volume of variability in the post-measurement ranged between (6.269 -15.792). There is also a correlation statistically significant between the play's lines and the variables of starting speed from stability, and zig-zag running with the ball, speed movement (in the direction of the midfield and offensive), and an inverse significant relation in the direction (midfield and defense) in sprint variables, speed endurance, rebound running, and a correlation is not significant in the starting speed from movement, and running with the ball 30 meters, running with the ball between 10 cones.
\end{abstract}

\section{Introduction:}

A gility is considered one of the most important elements of fitness for soccer field as it overlaps and linked with other elements such as speed, strength, flexibility and coordination, in addition to its close relation with dynamic performance and have an impact in variable situations during the game, as in the speed of the variation from one performance to another, and changing the player his direction or stop suddenly, or shooting after dribbling, or running to escape from a competitor to receive the ball. (1:158) (2:169) (3:434)

And agility drills in soccer are necessary to make the player dynamically faster, and increase muscle strength and improve the performance of the players and to maintain a balance when starting and stopping, as well as neuromuscular coordination in dynamic performances. (4: 18).
And Bangsbo (2009) adds that the speed and agility drills of great importance in the fitness program for soccer player, as the speed of play in modern soccer has increased than ever before, and when the endurance and strength are important in improving performance, the fastest player is the separator limit in the competition, and whatever you have endurance the ability to access to the ball faster remain the most important in performance. (5: 15).

According to soccer experts the speed factor is one of the most important variables of developing modern soccer, as it forms the basis for this development, and is considered an important determinant of the outcome of many games Speed is also linked to all other physical elements affects and is affected by, physical and skillful and tactical performance in soccer as a whole or in any part of it became not dispensed 
with speed through the reactions of the external and internal stimulus and very quickly

$(6: 285)(1: 120)(7: 95)$

Moreover Devries (1997),Frank dick (2007) mention that the speed can be developed with difficulty and in a lesser degree than other physical abilities as it is characterized with its confidentiality that linked to the nature of performance and flexibility of joints and stretching muscles, genetic factor that controls the formation of the number of fast and slow muscle fibers ratio and what follows that of the formation of the number of dynamic units, and by reducing the negative resistance and improve the degree of neuromuscular coordination. $(8: 37)(9: 451)$

Therefore Tumilty (1998), Strudwick (2002), confirm on the importance of developing the rates of speed with its different types of the players in all positions of play in soccer, due to the increasing need for them during the many changes happening in the duties of the players and their roles in the field, as well as the rapid changes in tactical sides whether it is innovative or recognized. (10: 239-242) (11: 16)

And also Hanafy Mukhtar (1989), Mufti Ibrahim (1990) and Hassan Abuabdh (2001), and Hernsuk (2003) refer to the importance of player's speed and the need to Perform movements of the play quickly as soon as possible under the available circumstances, and the tactical requirements and individual potential, especially the sprint by quick running to specific distances, as well as the speed of the starting, and the speed of motor performance of skills in various forms as the speed of running with the ball, passing and receiving and shooting. (12: 37) (14:284) (14:60) (15:284)

In the light of the previous display and through the nature and the diversity of speed in soccer activity, and the researcher's experience in the field of training and analysis of the games has been found that there are several reasons appear and crystallize research problem as follows:

- The researcher noticed during follow-ups to some competitions at the level of clubs and national teams North African players exceed the Egyptian players in short speeds, especially in offensive areas of the field
- The researcher noticed that a lot of Egyptian coaches are interested in developing speed endurance and neglect other speed abilities as (starting speed, sprint, and motor speed).

- The researcher noticed that the international and local commitments in soccer competitions and convergence and overlapping of training seasons helps to reduce the time of preparation, as well as pressure of matches in the local competition, with a break up to three days between the game and the next, Which works to compress physical training inclusions, and implementing it in a compound way may reach to omit some of its elements.

Based on the foregoing, it highlight the importance of this study in developing a new method for developing and improving speed abilities in soccer, and provide who works in the field of training a standardized training program aims at the development of speed and agility, in the light of one program for agility drills, which is considered a compound physical ability in which speed is a key element to soccer players.

\section{The aim of this research:}

The research aims to identify the effect of agility drills program on some speed abilities on junior soccer players under 17 years old.

\section{Materials and Methods:}

\section{Research approach:}

The researcher used the experimental method by designing (pre-measurement, postmeasurement) for one experimental group because of its appropriateness to the nature of this search.

\section{Research sample:}

Study sample was selected and made up of (26) junior representing original population of NBE team under 17 years old, registered at the junior phase in Giza district for soccer sports season 2010/2011, (3) players were excluded due to injury, making the number of main sample members (23) player (8 players at defense line, 7 at the center line, 8 at offensive line)

The coefficient of skewness in the variables under study has been calculated, and ranged between $(0.019-2.527)$ that is, it was limited between \pm 3 , Indicating the homogeneity of 
research sample and its location under the normal curve.

\section{Variables of speed abilities and Agility:}

-The test of starting speed from stability $(10 \mathrm{~m})$ to the nearest 1/10 S (16: 203)

-The test of starting speed from movement (10). (16: 203)

-Speed endurance in the last (40 yards) of running (120 yards)

(16: 203)

-The test of sprint and acceleration from stability (30).

(17: 125)

-The test of motor speed (wall pass). ( $1: 254)$

-The test of running speed and ball control (30 $\mathrm{m})$.

(17: 126)

-The test of shuttle running $(4 \times 10 \mathrm{~m})$. (17: 127)

-The test of zig-zag running $(25 \mathrm{~m})$ with the ball between (5) cones. ( $1: 259)$

-The test of running speed and control the ball between (10) cones. (18:19)

\section{Equipment and tools used in the research:}

The researcher used the following equipment and tools to help do the tests, and the proposed program, a (Ristameter) (cm), Medical Balance (Kg), Measuring tape (50 meters), (3) Stopwatch to the nearest $1 / 10 \mathrm{Sec}$, cones different sizes - hoops, barriers, training ladders - soccer balls - a whistle

instruments and devices used in drills and measurements, and directing assistants in the program.

\section{-Scientific transactions of tests:}

Studies conducted on similar samples (5) (16) (19) (18 ), agreed that these tests have high (validity - reliability) coefficients, the " $\mathrm{z}$ " value of validity coefficient to the current research sample between distinctive group and another non-distinctive was limited between (2.193 2.619), and the reliability coefficient between $(.949-.999)$ by test-retest, and it is statistically significant value at the level of 0.05 and so these tests can be used in the proposed program.

\section{The proposed training program:}

-The time of the daily training unit in the preparation program of the team between (70:120) minutes, and by (5) weekly training units.

-The allocated time for the development and refinement of the special agility in training unit in between (25 - 35) minutes during the period of the proposed program.

-Applying the proposed program of agility training from the beginning of the third week of the preparation period for (10) weeks, by (3) training units weekly with time interval not less than (48) hours between the unit and the next, where the player has in the first and the second weeks the constitutive section through endurance, strength, and flexibility drills.

-The section of agility drills begins after the warm-up period, and in the beginning of the main part of the training unit, since it puts a great burden on the central nervous system (1: 385)

-The basic components of agility drills in the program: Agility by running in curves and zigzag with and without the ball, Agility with flexibility, Agility with the ability, Agility with balance, Agility with coordination, Agility with skill in soccer.

-Researcher used the controlling of the load degree in legalization of the training load for the development of agility and some speed abilities, and that through fixing the intensity load, and relief, and the change in the amount of load (performance time) according to energy production systems.(13:385) (20:128) . 
Table (1) Training load of agility drills distribution in the proposed program for the sample under study

\begin{tabular}{|c|c|c|c|c|c|c|c|c|c|c|}
\hline \multirow{2}{*}{$\begin{array}{l}\text { week } \\
\text { number }\end{array}$} & \multirow{2}{*}{$\begin{array}{l}\text { intensity } \\
\text { of load }\end{array}$} & \multirow[b]{2}{*}{ Training number } & \multicolumn{5}{|c|}{ Amount(time/ seconds) } & \multicolumn{2}{|c|}{ Recovery } & \multirow{2}{*}{$\begin{array}{l}\text { Agility } \\
\text { time by } \\
\text { unit }\end{array}$} \\
\hline & & & $\begin{array}{l}\text { Set } \\
1\end{array}$ & $\begin{array}{l}\text { Set } \\
2\end{array}$ & $\begin{array}{l}\text { Set } \\
3\end{array}$ & $\begin{array}{l}\text { Set } \\
4\end{array}$ & $\begin{array}{l}\text { Set } \\
5\end{array}$ & $\begin{array}{l}\text { For } \\
\text { exercise }\end{array}$ & $\begin{array}{l}\text { Between } \\
\text { sets }\end{array}$ & \\
\hline 1,2 & \multirow{6}{*}{ Maximum } & $\begin{array}{l}(1,2,3,4,5,6) \\
a, b, c\end{array}$ & 30 & 45 & 45 & 60 & 45 & $\begin{array}{l}\text { from } \\
60-120 \\
\text { sec }\end{array}$ & $\begin{array}{l}5 \\
\text { Minute }\end{array}$ & $\begin{array}{l}30 \\
\text { Minute }\end{array}$ \\
\hline 3,4 & & $\begin{array}{l}(7,8,9,10,11,12) \\
a, b, c\end{array}$ & 30 & 60 & 60 & 45 & 60 & $\begin{array}{l}\text { from } \\
60-120 \\
\text { sec }\end{array}$ & $\begin{array}{l}5 \\
\text { Minute }\end{array}$ & $\begin{array}{l}35 \\
\text { Minute }\end{array}$ \\
\hline 5 & & $\begin{array}{l}(13,14,15) \\
a, b, c\end{array}$ & 30 & 30 & 60 & 30 & 45 & $\begin{array}{l}\text { from } \\
60-120 \\
\text { sec }\end{array}$ & $\begin{array}{l}5 \\
\text { Minute }\end{array}$ & $\begin{array}{l}35 \\
\text { Minute }\end{array}$ \\
\hline 6,7 & & $\begin{array}{l}(16,17,18,19,20,21) \\
a, b, c\end{array}$ & 15 & 20 & 20 & 30 & 20 & $\begin{array}{l}\text { from } \\
30-60 \\
\text { sec }\end{array}$ & $\begin{array}{l}4 \\
\text { Minute }\end{array}$ & $\begin{array}{l}30 \\
\text { Minute }\end{array}$ \\
\hline 8,9 & & $\begin{array}{l}(22,23,24,25,26,27) \\
a, b, c\end{array}$ & 15 & 30 & 30 & 20 & 30 & $\begin{array}{l}\text { from } \\
30-60 \\
\text { sec }\end{array}$ & $\begin{array}{l}4 \\
\text { Minute }\end{array}$ & $\begin{array}{l}35 \\
\text { Minute }\end{array}$ \\
\hline 10 & & $\begin{array}{l}(28,29,30) \\
a, b, c\end{array}$ & 15 & 15 & 30 & 15 & 20 & $\begin{array}{l}\text { from } \\
30-60 \\
\text { sec }\end{array}$ & $\begin{array}{l}4 \\
\text { Minute }\end{array}$ & $\begin{array}{l}25 \\
\text { Minute }\end{array}$ \\
\hline
\end{tabular}

Table (1) shows the intensity of load and amount and recovery of the training unit according to the time of energy production systems in the research to develop agility over (10) weeks duration of the program:

-Maximum amount: 3 set 100\%, 1 set $75 \%, 1$ set $50 \%$ - sub-maximum: 3 set $75 \%$, 1 set $100 \%$, 1 set $50 \%$ - average: 3 set $50 \%$, 1 set $100 \%$, program $75 \%$ - recovery is up to twice the performance time of the exercise, and $4-5$ minute for set.

Pre-measurement was conducted on sample members on Thursday, Friday 22 , $23 / 7 / 2010$ on the fields of the National Bank Club of Giza in all research variables

\section{Program application:}

The researcher applied the proposed program of agility drills in the period from Saturday $24 / 7 / 2010$ to Wednesday $29 / 9 / 2010$ by (3) weekly training units

\section{Post-measurements:}

Post-measurements conducted on Thursday, Friday 30/9, 1/10/2010 according to their ranking in the same conditions of their premeasurements for all research variables.

\section{Statistical treatments}

To achieve the objectives of the research researcher used the following statistical treatments:

arithmetic mean, standerd deviation, skweness coefficient, "Z" test, probabilities, correlation coefficient (person), volum of variability. 


\section{Results and Discussion:}

Table (2) differences significance between the pre-measurement and post-measurement in variables under study $\mathrm{n}=23$

\begin{tabular}{|c|c|c|c|c|c|c|c|c|}
\hline \multirow{2}{*}{ Variables } & $\begin{array}{l}\text { The } \\
\text { whole } \\
\text { sample }\end{array}$ & $\mathrm{n}=23$ & $\begin{array}{l}\text { defens } \\
\text { e }\end{array}$ & $\mathrm{n}=8$ & $\begin{array}{l}\text { midfie } \\
\text { ld }\end{array}$ & $\mathrm{n}=7$ & $\begin{array}{l}\text { Offens } \\
\text { ive }\end{array}$ & $n=8$ \\
\hline & $\begin{array}{l}\text { "Z" } \\
\text { value }\end{array}$ & $\mathrm{P}$ & $\begin{array}{l}\text { "Z" } \\
\text { value }\end{array}$ & $\mathrm{P}$ & $\begin{array}{l}\text { "Z" } \\
\text { value }\end{array}$ & $\mathrm{P}$ & $\begin{array}{l}\text { "Z" } \\
\text { value }\end{array}$ & $\mathrm{P}$ \\
\hline $\begin{array}{l}\text { Starting } \\
\text { speed from } \\
\text { stability }\end{array}$ & $* 4.201$ & .000 & $\begin{array}{l}2.524 \\
*\end{array}$ & .012 & $\begin{array}{l}2.366 \\
*\end{array}$ & .018 & $\begin{array}{l}2.533 \\
*\end{array}$ & .011 \\
\hline $\begin{array}{l}\text { Starting } \\
\text { speed from } \\
\text { movement }\end{array}$ & $* 4.203$ & .000 & $\begin{array}{l}2.536 \\
*\end{array}$ & .011 & $\begin{array}{l}2.375 \\
*\end{array}$ & .018 & $\begin{array}{l}2.524 \\
*\end{array}$ & .012 \\
\hline sprint & $* 4.203$ & .000 & $\begin{array}{l}2.524 \\
*\end{array}$ & .012 & $\begin{array}{l}2.379 \\
*\end{array}$ & .017 & $\begin{array}{l}2.527 \\
*\end{array}$ & .012 \\
\hline $\begin{array}{l}\text { Speed } \\
\text { endurance }\end{array}$ & $* 3.51$ & .000 & $\begin{array}{l}2.539 \\
*\end{array}$ & .011 & $\begin{array}{l}2.375 \\
*\end{array}$ & .018 & 2.409 & .012 \\
\hline $\begin{array}{l}\text { Running } 30 \\
\mathrm{~m} \text { with ball }\end{array}$ & $* 4.2$ & .000 & $\begin{array}{l}2.527 \\
*\end{array}$ & .012 & $\begin{array}{l}2.366 \\
*\end{array}$ & .018 & $\begin{array}{l}2.521 \\
*\end{array}$ & .012 \\
\hline $\begin{array}{l}\text { Running with } \\
\text { ball between } \\
\text { cones }\end{array}$ & $* 4.199$ & .000 & $\begin{array}{l}2.524 \\
*\end{array}$ & .012 & $\begin{array}{l}2.371 \\
*\end{array}$ & .018 & $\begin{array}{l}2.533 \\
*\end{array}$ & .011 \\
\hline $\begin{array}{l}\text { Zig-zag with } \\
\text { ball }\end{array}$ & $* 4.199$ & .000 & $\begin{array}{l}2.521 \\
*\end{array}$ & .012 & $\begin{array}{l}2.366 \\
*\end{array}$ & .018 & $\begin{array}{l}2.521 \\
*\end{array}$ & .012 \\
\hline $\begin{array}{l}\text { Shuttle } \\
\text { running }\end{array}$ & $* 4.199$ & .000 & $\begin{array}{l}2.524 \\
*\end{array}$ & .012 & $\begin{array}{l}2.375 \\
*\end{array}$ & .018 & $\begin{array}{l}2.524 \\
*\end{array}$ & .012 \\
\hline $\begin{array}{l}\text { Speed } \\
\text { movement }\end{array}$ & $* 4.2$ & .000 & $\begin{array}{l}2.521 \\
*\end{array}$ & .012 & $\begin{array}{l}2.366 \\
*\end{array}$ & .018 & $\begin{array}{l}2.533 \\
*\end{array}$ & .011 \\
\hline
\end{tabular}

"z" value at the level of $0.05=1.96$ 
Table (3) Volume of variability of the post-measurement from pre-measurement in variables under study

\begin{tabular}{|c|c|c|c|c|c|c|c|c|c|c|c|c|}
\hline \multirow[b]{2}{*}{ variable } & \multicolumn{3}{|l|}{$\begin{array}{l}\text { The } \\
\mathrm{n}=23\end{array}$} & \multicolumn{3}{|c|}{$\begin{array}{l}\text { Defense line } \\
=8\end{array}$} & \multicolumn{3}{|c|}{$\begin{array}{l}\text { Midfield } \\
=7\end{array}$} & \multicolumn{3}{|c|}{ Offensive line } \\
\hline & pre & post & $\begin{array}{l}\text { Volu } \\
\text { me of } \\
\text { variab } \\
\text { ility } \\
\%\end{array}$ & pre & post & $\begin{array}{l}\text { Volum } \\
\text { e of } \\
\text { variabi } \\
\text { lity } \\
\%\end{array}$ & pre & post & $\begin{array}{l}\text { Volum } \\
\text { e of } \\
\text { variabi } \\
\text { lity } \\
\%\end{array}$ & pre & post & $\begin{array}{l}\text { Volum } \\
\mathrm{e} \text { of } \\
\text { variabi } \\
\text { lity } \\
\%\end{array}$ \\
\hline $\begin{array}{l}\text { Starting } \\
\text { speed } \\
\text { from } \\
\text { stability }\end{array}$ & 5.298 & 4.613 & 12.926 & 5.338 & 4.700 & 11.944 & 5.357 & 4.657 & 13.067 & 5.206 & 4.488 & 13.806 \\
\hline $\begin{array}{l}\text { Starting } \\
\text { speed } \\
\text { from } \\
\text { moveme } \\
\text { nt }\end{array}$ & 1.681 & 1.461 & 13.085 & 1.730 & 1.506 & 12.934 & 1.733 & 1.524 & 12.036 & 1.588 & 1.361 & 14.252 \\
\hline sprint & 5.095 & 4.627 & 9.191 & 5.079 & 4.581 & 9.796 & 5.060 & 4.639 & 8.329 & 5.141 & 4.661 & 9.336 \\
\hline $\begin{array}{l}\text { Speed } \\
\text { enduranc } \\
\text { e }\end{array}$ & 5.567 & 5.218 & 6.269 & 5.530 & 5.193 & 4.295 & 5.449 & 5.041 & 7.487 & 5.721 & 5.421 & 5.244 \\
\hline $\begin{array}{l}\text { Running } \\
30 \quad \mathrm{~m} \\
\text { with ball }\end{array}$ & 13.574 & 12.031 & 11.365 & $\begin{array}{l}13.31 \\
5\end{array}$ & 11.813 & 11.284 & 13.656 & 12.196 & 10.691 & 13.761 & 12.106 & 12.027 \\
\hline $\begin{array}{l}\text { Running } \\
\text { with ball } \\
\text { between } \\
\text { cones }\end{array}$ & 14.030 & 12.916 & 7.937 & $\begin{array}{l}13.99 \\
4\end{array}$ & 13.049 & 6.753 & 13.966 & 12.703 & 9.043 & 14.121 & 12.970 & 8.153 \\
\hline $\begin{array}{l}\text { Zig-zag } \\
\text { with ball }\end{array}$ & 13.926 & 11.727 & 15.792 & $\begin{array}{l}14.10 \\
5\end{array}$ & 11.964 & 15.181 & 13.837 & 11.614 & 16.064 & 13.824 & 11.588 & 16.177 \\
\hline $\begin{array}{l}\text { Shuttle } \\
\text { running }\end{array}$ & 10.325 & 9.624 & 6.784 & $\begin{array}{l}10.32 \\
5\end{array}$ & 9.595 & 7.070 & 10.206 & 9.443 & 7.475 & 10.429 & 9.813 & 5.909 \\
\hline $\begin{array}{l}\text { Speed } \\
\text { moveme } \\
\text { nt }\end{array}$ & 13.795 & 12.058 & 12.594 & $\begin{array}{l}13.85 \\
0\end{array}$ & 12.150 & 12.274 & 13.741 & 12.063 & 12.217 & 13.794 & 11.947 & 13.391 \\
\hline
\end{tabular}

The results of tables (2), (3) illustrate that there are statistically significant differences - for postmeasurement in all speed and agility variables under study, and the new in this study is the development of speed through agility drills, while researchers adopted in previous studies on the speed exercises for developing speed abilities. Where the "Z" values of the sample as a whole ranged between (3.51 -4.203), and in the defense line between $(2.521-2.539)$ the midfield (2,366-2.379), offensive line (2.521 2.533), all of it is statistically significant at the level of 0.05 .

Researcher attributed these differences to the effect of the proposed training program for the development of agility, which was applied to research sample through the special two stages of preparation, and before competitions, Where it was characterized by precision in agility drills design and selection, and pay attention to the balanced development of agility components, and the proper succession in line with the objective targets for the program, and content in this age stage.

And this is consistent with the results of Mohammed Batal, Ibrahim Hegab study (1989) (21), Taha Ismail et al (1989) (1), Ali Albeack (1992) (22) and what Aboulela Abdel-Fattah refers to (1997) (23), that there is a correlation relation between agility and each of general speed, coordination, and strength characterized by speed, and to upgrade and improve the abilities of speed standardized scientific programs of agility should be used by 
improving the ability of the central nervous system and coordination within the muscle.

The researcher also attributed these differences to the legalization of agility drills in the proposed program in defense line, midfield, offensive line according to the performance nature in soccer and energy production systems (the glycogenolysis - ATP-PC) and using the high intensity interval training method, which suit the development of agility with its essential components such as speed, capacity, flexibility, coordination and balance. And what proves that is the volume of variability and improvement in post-measurement, ranging in defense line between (5.909 - 12.934) and midfield ( 4.903 13.391) and offensive line (2.715 - 14.617), and the sample as a whole between $(3,928-15.792)$.

And this is consistent with the study results of, Hanafy Mukhtar (1988) (20), Ismail Ashour (1989) (6), Mohammed Ibrahim (1990) (24) , Ehab Hussein (1996) (25), Hassan Abu Abda (2001) (14), Bangsbo (2009) (5).

Table (4) differences significance between the play's "defense, midfield, offensive" post- lines in the measurement in variables under study

\begin{tabular}{|c|c|c|c|c|c|c|}
\hline Variables & positions & number & $\begin{array}{l}\text { Mean } \\
\text { rank }\end{array}$ & D F & $\begin{array}{l}\text { "z" } \\
\text { value }\end{array}$ & probability \\
\hline \multirow{3}{*}{$\begin{array}{l}\text { Starting speed from } \\
\text { stability }\end{array}$} & defense & 8 & 15.31 & \multirow{3}{*}{2} & \multirow{3}{*}{4.488} & \multirow{3}{*}{.106} \\
\hline & midfield & 7 & 12.57 & & & \\
\hline & offensive & 8 & 8.19 & & & \\
\hline \multirow{3}{*}{$\begin{array}{l}\text { Starting speed from } \\
\text { movement }\end{array}$} & defense & 8 & 15.38 & \multirow{3}{*}{2} & \multirow{3}{*}{3.197} & \multirow{3}{*}{.202} \\
\hline & midfield & 7 & 10.93 & & & \\
\hline & offensive & 8 & 9.56 & & & \\
\hline \multirow{3}{*}{ sprint } & defense & 8 & 13.81 & \multirow{3}{*}{2} & \multirow{3}{*}{.882} & \multirow{3}{*}{.643} \\
\hline & midfield & 7 & 11.07 & & & \\
\hline & offensive & 8 & 11.00 & & & \\
\hline \multirow{3}{*}{ Speed endurance } & defense & 8 & 12.06 & \multirow{3}{*}{2} & \multirow{3}{*}{1.739} & \multirow{3}{*}{.419} \\
\hline & midfield & 7 & 9.50 & & & \\
\hline & offensive & 8 & 14.13 & & & \\
\hline \multirow{3}{*}{$\begin{array}{l}\text { Running } 30 \mathrm{~m} \text { with } \\
\text { ball }\end{array}$} & defense & 8 & 8.75 & \multirow{3}{*}{2} & \multirow{3}{*}{2.955} & \multirow{3}{*}{.228} \\
\hline & midfield & 7 & 14.43 & & & \\
\hline & offensive & 8 & 13.13 & & & \\
\hline \multirow{3}{*}{$\begin{array}{l}\text { Running with ball } \\
\text { between cones }\end{array}$} & defense & 8 & 13.88 & \multirow{3}{*}{2} & \multirow{3}{*}{2.428} & \multirow{3}{*}{.297} \\
\hline & midfield & 7 & 8.71 & & & \\
\hline & offensive & 8 & 13.00 & & & \\
\hline \multirow{3}{*}{ Zig-zag with ball } & defense & 8 & 15.00 & \multirow{3}{*}{2} & \multirow{3}{*}{2.446} & \multirow{3}{*}{.294} \\
\hline & midfield & 7 & 10.00 & & & \\
\hline & offensive & 8 & 10.75 & & & \\
\hline \multirow{3}{*}{ Shuttle running } & defense & 8 & 15.56 & \multirow{3}{*}{2} & \multirow{3}{*}{4.326} & \multirow{3}{*}{.115} \\
\hline & midfield & 7 & 8.29 & & & \\
\hline & offensive & 8 & 11.69 & & & \\
\hline & defense & 8 & 12.50 & & & \\
\hline Speed movement & midfield & 7 & 10.64 & 2 & .406 & .816 \\
\hline & offensive & 8 & 12.69 & & & \\
\hline
\end{tabular}


As table (4) shows that there are differences not statistically significant in post-measurement between the play lines "defense, the midfield, the offensive " in the research variables, and the researcher attributed that to the importance of these abilities to all the players as it is considered the most crucial factors in superiority over the opponent in modern soccer. The agility drills has played a key role in the convergence of the results of the players of defense, midfield and offensive lines in these variables.

Although the statistical differences are not significant between the play's "defense, midfield and offensive" lines but it refers to the superiority of "offensive line" where it achieved the best averages in the times of tests of starting speed from stability (4.488) and from movement (1.361), and zig-zag running with the ball between (5) cones (11.588), and motor speed ( 12.15).

Researcher attributes these results to the nature of the performance in this position which requires that the striker has the ability to get rid of the defender by movement and quick starting surprisingly, in addition to the deception and zig-zag running with the ball in areas crowded with players, and this is consistent with what mentioned by and Ali Albeack (1992) (22), DEVRIES (1997) (8), and Adel Alfady (2004) (26), and Little \& William (2005) (4) that agility drills (ability agility using barriers) works on improving starting speed and acceleration for short distances, and help to improve the explosive movements of the two legs .

And the "midfield" achieved best averages of times of the test of : speed endurance reached Table (5) the correlation coefficient between play's "defense, midfield, offensive" lines and variables under study in the post-measurement

\begin{tabular}{l|l}
\hline Study variables & Play's lines \\
\hline Starting speed from stability & 0.415 \\
\hline Starting speed from movement & $* 0.227$ \\
\hline sprint & $* 0.464-$ \\
\hline Speed endurance & $* 0.626-$ \\
\hline Running 30 m with ball & 0.059 \\
\hline Running with ball between cones & 0.354 \\
\hline
\end{tabular}

(5.041), shuttle run (9.443), running with the ball between (10) cones (12.703), and these results are attributed to the nature of the performance of midfielders, which requires the ability to repeat running with or without the ball under opponent's pressure, this may be done beginning with the preparation stage for the attack and to the construction stage and finishing, which leads the player to reach the state of adaptation in performance .

And this is consistent with what each of Taha Ismail et al (1989) (1), Mohammed Ibrahim Shehata (1997) (24), Ghazi Youssef, and Ibrahim Saleh (1998) (27), a study by Mohamed keshk and Amralla Bosatti (2002) ( 16), Adel Alfady (2004) (26), William \& Little (2005) (4) referred to which shows that the midfielders have achieved the better rates of speed endurance and they justified it that the player needs to keep at high speed rate and performance timing like speed endurance, performance endurance, and these speeds are the basis for the implementation of play's plans and create opportunities of shooting, and this appears in the agility drills (shuttle run) as it in addition to improving the speed and balance is working on the development of speed endurance.

-"defense line" also achieved the best average time in (running with the ball $30 \mathrm{~m}$ ) test, was (11.813), the sprint (4.581).

Researcher attributes the superiority of the defense line in these two variables to the player moving with the ball in a straight line in areas relatively empty, which is always repeated in defense area and on the edge of the field in wings area, Adel Alfady (2004) (26). Rifai Mustafa (2009) (28), supported that. 


\begin{tabular}{l|l}
\hline Zig-zag with ball & $* 0.532$ \\
\hline Shuttle running & $* 0.492-$ \\
\hline Speed movement & $* 0.479$ \\
\hline cor..." value at the level of $0.05=0.413$
\end{tabular}

Table (5) shows the results of correlation coefficients between the three play lines "defense, the midfield, offensive ", and speed and agility variables in the proposed program, where the aspects of benefit between the play lines varied according to the requirements of each line in the activity of soccer. Through a review of the post-measurement results, there is a statistically significant correlation in the direction of "midfield and offensive" lines where the correlation coefficient values of the variables of: the starting speed from stability (0.405),zigzag running with the ball (.532), motor speed (0.479) and all of them statistically significant values at the level of 0.05 .

Researcher attributes these correlations to the importance of these abilities to the players in midfield and offensive lines, which commensurate with the nature of their performance, in which agility plays a major role that appears in getting rid of defender pressure during running short distances by starting speed, dribbling and control by zigzag running, to complete purposefully planned work.

And this is consistent with what Abo elela Abd ElFattah, Ibrahim Shaalan (1994) (29), Amr Allah Bosatti (1995) (2), and Hassan Saud's study (2002) (30) and Adel Alfady (2004) (26) referred to that the strikers achieved the highest averages in the short running tests $(15,30 \mathrm{~m})$, and the nature of the offensive player duties requires high-intensity effort for a short period of time.

While Table (5) shows that there is correlations not statistically significant between the play's lines "defense, midfield, offensive line" and the variables of: starting speed from movement (10 $\mathrm{m})$ in which the value of the coefficient of correlation reached (0.427), and running with the ball $(30 \mathrm{~m})$ was $(.059)$, and running with the ball between (10) cones ( 0.354$)$, and all of them are values not statistically significant at the level of 0.05 .

Researcher attributes this to the nature of the modern soccer activity that requires from the player the ability to perform in any of the different play positions as necessary during the match and the play's plan, especially performing running and controlling the ball skills, which are considered one of the fundamental skills that must be mastered by all the players in all the play's lines, or quick navigation without the ball from one place to another from stability, or from movement to take appropriate positions on the field, or rapid shift from defense to attack and the contrary throughout the game time, and what proves that is the volume of variability and improvement of these variables in postmeasurement.

The results of table (5) also show that there is an inverse correlation statistically significant relation between the play's lines "defense, midfield, offensive line" in the direction of "midfield, defense" lines of sprint variables with coefficient of correlation (.464), speed endurance (0.626), shuttle running (0.492).

Researcher attributes this inverse correlation relation to the impact of some agility drills of the proposed program such as shuttle running, and bounces in some parts of the exercise whether above the cones or using barriers that contribute to the development of sprint, and speed endurance, and shuttle running, in addition to the nature of the performance of midfield and defense players which use long and short running spaces, and repeat it during the game which commensurate with the nature of the play's modern systems in which the number of defenders reduced to provide an opportunity for offensive work with a large number of players who should have high level of speed for proper and appropriate positioning, and inverse coverage and take defensive positions as quickly as possible, and the shift from defense to attack and vice versa. .And this is consistent with what Ryder jj (2004) (31), Arnason (2004) (32) see that the midfielders are the most soccer players in covering field's areas, and certainly for small distances and the speeds that exceed $(10 \mathrm{~m})$ and used it in defense and attack to open the loopholes. And what Adel 
Alfady's study indicates that defense players have achieved the highest rate in the averages of running test 30 meters with the midfielders.

\section{Conclusions:}

In the light of the objectives and within the research sample and procedures researcher was able to reach to the following conclusions:

1 - Agility Training Program has a positive effect on the development of the selected speed and agility abilities to the juniors U-17 research sample with statistically significant differences.

2 - Agility training program have a positive impact on the development of speed and agility to play's lines "defense, midfield, offensive" the research sample with statistically significant differences in the post-measurement of every one.

3 - Benefit degrees varied between play's lines "defense, midfield, offensive" despite there is no statistically significance of the results of speed and agility abilities in the post-measurement, so the best averages came to offensive line in starting speed from stability and movement, zigzag running with the ball, motor speed, and the midfield in speed endurance, shuttle running, and defense line in running with the ball in a straight line.

4 - That the volumes of variability and improvement in the speed and agility variables came in favor of the post-measurement as a result of applying the proposed program on research sample and it ranged between (4.29516.177) in the three play's lines.

5 - There is a correlation statistically significant relation in the direction of "midfield and offensive" lines in the variables (starting speed from stability, zig-zag running with the ball, motor speed), and an inverse relation in the direction of midfield and defense lines in the variables (speed endurance, sprint "30 m", shuttle running), and correlation not statistically significant relation in the variables: starting speed from movement, running with the ball between (10) cones, running with the ball in a straight line $(30 \mathrm{~m})$.

\section{Recommendations:}

By displaying and interpretation of the results, and within the research sample the researcher recommends the following:

1 - Directing the results of this research and agility proposed program and its implementation steps to workers in the field of soccer training to take advantage of them.

2 - Paying attention to agility drills with its various components, especially in the private preparation stage, and pre-competitions stage because of its positive impact on the development of speed and agility abilities in soccer.

3-The use of agility proposed program, especially in short preparation periods in training seasons overlapping and crowded with championships.

4- Paying attention to the planning of agility drills programs in soccer according to energy production systems which takes into account individual differences among individuals.

5 - Conduct such a study in other sport activities and link it to basic skills. 


\section{References:}

1 - Taha Ismail, Amr Abu Almagd, Ibrahim Shaalan (1989): Soccer between theory The application, physical preparation, Arab Thought House, Cairo.p158 -162 (in Arabic)

2 - Amr Allah Albosatti (1995): Coaching and physical preparation in soccer, knowledge Institution,Alexandria. (in Arabic)

3 - Ahmed Khater, Ali Albeack (1996): Measurement in the sports field, Fourth Edition, The Modern Book House, Alexandria. (in Arabic)

4- little, t . and a .g . Williams (2005) : speecificty of acceleration maximum spead, and agility in professional soccer players , $\mathrm{j}$ strength condres .

5- Bangsbo , j . (1994): fitness training in soccer, Copenhagen ho + bagsaverd .

6 - Ismail Abd Zead ashour (2009): The impact of the proposed training program for speed in football, published research, the bulletin of Sports Science, the first edition, the University of Diyaly, Iraq.(in Arabic).

7 - Mohammed Abdu Saleh Alwahsh, Mufti Ibrahim (1994): Soccer fundamentals, fulfill house,Mansoura (in Arabic)

8- Devries Herbert a ., (1986) : physiology of exercise for physical education and athletics, brown publishers Dubuque, lowa fourth edition .

9- Frank dick w , (2007) : sports training principles, second edition a \&c black, London .

10- Tumilty , d . (1998) phiciological characteris of elite soccer players, Australian institute tics of sport medicine journal vol

11- Strudwick a , reilly t , dorna d, (2002) : anthropometric and fitness of elite players two football codes, jurnal sports medicine physical fitness livarpool , united kingdom , (42)

12 - Hanafy Mukhtar, Mufti Ibrahim (1989): physical preparation in soccer, Zahran, House, Cairo. (in Arabic)

13 - Mufti Ibrahim (1990): the attack in soccer, Arab Thought House, Cairo.(in Arabic).

14 - Hassan El Sayed Abu Abdah (2001): Recent trends in planning and coaching soccer, Radiation printing press, Alexandria. (in Arabic)

15 - T. D. Hernsuk and others (2003): Foreign students notebook in the theories and methods of special training in soccer, faculty of Mathematical Sciences. Leipzig, Germany

16- Muhammad keshk, Amr Allah Albosatti (2002):The impact of plymetric drills at Horizontal and vertical directions on the level of the explosive power and 
speed vehicles of some athletes, published research, the scientific journal "theories and applications" Faculty of Physical Education for Boys, Alexandria University. (in Arabic)

17- jens rehhagel:(2011) entwicklungeiner test batterie zur diagnostic und steuerung der schnelligkeit im sports piel fub ball, dissertation, institute fur bewegung .und neuro wissenschaft der deutschen sporthochschule koln.

18- peter roth, erhard thiel ; (1987) : dersporttalent . tests, Wilhelm gold man verlag, muenchen .

19- Mohammed, keshk (1996): the impact of developing special endurance using ring training style on some components of speed in soccer players, Assiut Journal of Physical Education Sciences, No. 6, Part II, November, Assiut University. . (in Arabic).

20 - Hanafy Mukhtar (1988): The basis of Planning sports training programs, Zahran, House, Cairo. (in Arabic).

21 - Muhammad Batal, Ibrahim Hegab (1989): the impact of a proposed program for the development of agility on the digital level of 110 meters hurdles competition. (in Arabic).

22 - Ali Fahmy Albeah (1992): The basis of preparing soccer and collective games players, the first edition Touny printing press, Alexandria. (in Arabic).

23- Abu Alela Abdel Fattah (1997): athletic training, "the physiological basis," Arab Thought House, Cairo. (in Arabic).

24 - Mohamed Ibrahim Shehata (1997): training with weights, knowledge institution, Alexandria. (in Arabic).

25 - Ehab Hussein (1996): the impact of the development of agility and flexibility on the digital level in high jump (Vosbery) for beginners, published research, bulletin of theories and applications. Faculty of Physical Education, Alexandria University (in Arabic).

26 - Adel Abd Alhamid Alfady (2004): Some physical and functional aspects of the players of various play's lines in soccer, published research, bulletin of theories and applications, number fifty second, Faculty of Physical Education for Boys, the University of Alexandria. (in Arabic).

27 - Ghazi Youssef, Ibrahim Saleh (1998): Recent trends in soccer coaching, College of Physical Education, University of Zagazig. (in Arabic).

28 - Refai Mustafa (2005): Origins of soccer coaching, the first edition, Amer for Printing and Publishing, Mansoura. (in Arabic).

29 - Abu Alela Abdel Fattah, Ibrahim Shaalan (1994): Coaching physiology in soccer, 
Arab Thought House, Cairo. (in Arabic).

30 - Hassan Al Saud (2005): A comparative study of some indicators of anaerobic ability between the players of different lines in soccer, published research, Faculty of Sport Sciences, University of Mutah, Baghdad. (in Arabic).

31- ryder jj , cotterell d, kellatt dw, lafferty m brodia da (2004): an i nvestigation into the, impact of limiting the number of matches of competitive soccer on the fitness of elite youth team soccer players aged 10 and 11 years old. University of Cambridge , journal of physiology p.555.

32-Arnason a , siguardsson. Sb , (2004) : gudman a , holme I,engebetsen 1, bahr $r$,physical fitness, injuries, and team performance in soccer , medicine , science and sport exercise , $\operatorname{vol}(36) \mathrm{p}-243-285$. 